\title{
The Legal Substance Ownership of Motor Vehicle Owner's Book
}

\author{
Etna Yesinia Mardianti ${ }^{*}$ and Maryanto** \\ *) Student of Master of Law, Faculty of Law, Universitas Islam Sultan Agung \\ Semarang, E-mail: etnayesinia@gmail.com \\ ${ }^{* *}$ Lecturer of Faculty of Law, Universitas Islam Sultan Agung Semarang
}

\begin{abstract}
.
The purpose of this research is to analyze the legal substance concerning the Motor Vehicle Ownership Book in terms of current positive legal aspects. The research method in this article is normative juridical. The results showed that the normative law of ownership of proof of ownership of motor vehicles has legal force as a means of protecting society and providing legal certainty. The strategic role of the BPKB as a valid means of evidence and its legitimacy is recognized by the State, in addition to that as a means of uncovering crimes related to motorized vehicles, both as objects (targets) of crime and as predicate of crimes (means or means). BPKB's juridical ownership scheme, rooted in the Preamble of 1945 Constitution of the Republic of Indonesia up to laws and regulations such as Act No. 22 of 2009 concerning Road Traffic and Transportation as well as Regulation of the Chief of Police Number 5 of 2012 concerning Registration and Identification of Motor Vehicles.

Keywords: Legal Certainty; Legal Protection; Vehicle Owners Book.
\end{abstract}

\section{Introduction}

Road traffic and transportation is a necessity for citizens to interact socially in an effort to achieve a prosperous life. The role of the State is present in carrying out regulatory functions so that the realization of Traffic and Road Transportation services that are safe, safe, orderly, smooth, and integrated with other modes of transportation to encourage the national economy, promote public welfare, strengthen national unity and integrity, and be able to uphold dignity nation. ${ }^{1}$ In addition, it is also necessary to realize traffic ethics and national culture and law enforcement and legal certainty for the community.

Motorized Vehicle is any vehicle that is driven by mechanical equipment in the form of a machine other than a vehicle that runs on rails. ${ }^{2}$ As one of the transportation actors on the highway, motorized vehicles need registration and identification of motorized vehicles. All of these are intended to (a.) Orderly administration, (b.) Control and supervise Ranmor, (c.) Facilitate investigation of violations and/or crimes, (d.) Planning, operational management and engineering of traffic and road transportation and (e.) national development planning.

Orderly administration of motor vehicles related to its jurisdiction is the guarantee of the validity of Ranmor and its ownership and operational of Ranmor in the context of realizing protection and legal certainty. Meanwhile, in the aspect of controlling and supervising motor vehicles, registration and identification of motorized vehicles aims to facilitate the investigation of violations and/or crimes.

\footnotetext{
${ }^{1}$ Article 3, Act No. 22 of 2009 concerning Road Traffic and Transportation

${ }^{2}$ Ibid. Article 1
} 
Finally, the function of registration and identification of motorized vehicles is related to providing data to support the law enforcement process against traffic violations. The police provide protection, protection and services to the community, as the existence of the Indonesian National Police (Polri) together and unite with the community. In such a position, it is only natural that the Polri performance evaluation is directly provided by the public ${ }^{3}$

Motorized Vehicle Owner's Book, hereinafter abbreviated as BPKB, is a document that legitimizes Ranmor ownership issued by the National Police and contains the identity of Ranmor and owner, which is valid as long as the Ranmor is not transferred. ${ }^{4}$ Legitimacy according to legal optics means that the BPKB is a legal recognition that exists in the community and it can be said that there is still a connection with legal acts that have already been applied as well as various legal and established laws, which include formal legal regulations, ethnic laws, customary law as well as social law that already exists in the community and its validity is recognized, so that by looking at the explanation above, legitimacy is indeed very important in the life of the wider community. ${ }^{5}$ The essence of the limitation of legal legitimacy is the existence of public trust and recognition that the BPKB is a legal document that can be used as a means of evidence for examining legal cases. As the function of a rule of law, a state that enforces the law optimally, upholds human rights and guarantees citizens equal position in the law and government is obliged to uphold the law and government without exception. ${ }^{6}$.

In connection with the juridical diction related to BPKB ownership being one of the main points of view of the community in carrying out legal culture, this research begins with the question of how is the normative law regarding Motor Vehicle Ownership Books in terms of current positive legal aspects? In this study, researchers limit the normative juridical ownership of BPKB in the realm of criminal law. The purpose of this article is to analyze the legal substance of BPKB ownership in terms of current positive legal aspects.

\section{Research methods}

The research method is a system and a process that absolutely must be carried out in a scientific research and development activity. ${ }^{7}$ This research uses a normative juridical method, which is research conducted by collecting research

\footnotetext{
${ }^{3}$ Setiyanto, Gunarto, Sri Endah Wahyuningsih, Efektivitas Penerapan Sanksi Denda E-Tilang Bagi Pelanggar Lalu Lintas Berdasarkan Undang-Undang Nomor 22 Tahun 2009 Tentang Lalu Lintas Dan Angkutan Jalan (Studi Di Polres Rembang), Jurnal Hukum Khaira Ummah Vol. 12. No. 4 December 2017, p. 756

${ }^{4}$ Article 1, Regulation of the Head of the National Police of the Republic of Indonesia Number 5 of 2012 concerning Registration and Identification of Motor Vehicles

5Understanding Political Legitimacy and Power According to Experts, https://www.weschool.id/pengentuk-legitimasi-hukum-politik-dan-kekdaya-menurut-para-ahli/

${ }^{6}$ Sri Endah Wahyuningsih dan Rismanto, Jurnal, Kebijakan Penegakan Hukum Pidana terhadap Penanggulangan Money Laundering dalam Rangka Pembaharuan Hukum Pidana di Indonesia, Jurnal Pembaharuan Hukum, Volume 2 No 1, January-April 2015, p. 47

7 Ira Alia Maerani, Jurnal, Implementasi Ide Keseimbangan dalam Pembangunan Hukum Pidana Indonesia Berbasis Nilai-Nilai Pancasila, Jurnal Pembaharuan Hukum, Volume 2 No 2, May-August 2015, p. 331.
} 
data through document study or literature study which is used to solve research problems. ${ }^{8}$ The analytical descriptive research specification was chosen as a means of describing the legal norms of the BPKB. According to Sri Endah and Rismanto, an analytical description is research that describes the prevailing laws and regulations and is associated with legal theories. ${ }^{9}$ While the data mining technique in this paper explores secondary data through data collection methods which are carried out using library research or library research.

\section{Results and Discussion}

Legal juridical analysis of BPKB ownership as evidence in the event of a criminal act is formulated in the following juridical formulation phrases:

- Protection and legal certainty

- Make it easier to investigate violations and/or crimes

- Provision of data to support law enforcement against traffic violations.

Thus this study analyzes comprehensively the three aspects in the main points above. Phrases or diction in juridical formulations in statutory regulations always keep the principles and objectives of the rules or legal norms which become a limitation or measure of a sense of justice even though it is only limited to legality. As a source of law, the author refers to Act No. 22 of 2009 concerning Road Traffic and Transportation, Presidential Regulation of the Republic of Indonesia Number 5 of 2015 concerning the Implementation of a One-Stop Administration System for Motor Vehicles and Regulation of the Head of the National Police of the Republic of Indonesia Number 5 of 2012 concerning Registration and Motor Vehicle Identification.

\subsection{Protection Norms and Legal Certainty}

The scheme of protection and legal certainty of ownership of a Motor Vehicle Ownership Book (BPKB) through Resident, namely Registration and Identification of Motor Vehicles, hereinafter abbreviated as Resident Ranmor, is the function of the Police to provide legitimacy of origin and worthiness, ownership and operation of Ranmor, control function, Police forensic and services to the public through verification, recording and data collection, numbering, issuing and providing proof of registration and identification of Ranmor, filing and providing information, based on: 10

- The preamble to the 1945 Constitution, the fourth paragraph, that is, one of the objectives of the establishment of a state government is to provide protection for the entire nation and all spilled Indonesian blood.

- Article 28G paragraph (1) and Article 28H paragraph (4) of the 1945 Constitution. Resident is a form of fulfilling the human rights of every citizen and resident of Indonesia. As described in Article 28G paragraph (1), "every

\footnotetext{
${ }^{8}$ Soerjono Soekanto and Sri Mamudji. (1985). Penelitian Hukum Normatif Suatu Tinjauan Singkat. Jakarta: Rajawali, p.52.

${ }^{9}$ Ibid. Sri Endah Wahyuningsih. p. 49.

10 General provisions, Regulation of the Head of the National Police of the Republic of Indonesia Number 5 of 2012 concerning Registration and Identification of Motor Vehicles.
} 
person has the right to protection of dignity, body and soul and property". Furthermore, in article $28 \mathrm{H}$ paragraph (4), "every person has the right to have private property rights and private property rights may not be confiscated by anyone by arbitrary means".

- Article 14 paragraph 1 letter I, Act No. 2 of 2002 concerning the Indonesian National Police. The juridical formulation in this article is as follows:

- "(1) In carrying out the main tasks referred to in Article 13, the Indonesian National Police have the duties: i. protect the safety of body and soul, property, society, and the environment from disturbances of order and/or disaster, including providing assistance and assistance by upholding human rights "

- Article 64 of Act No. 22 of 2009, through its juridical formulation is as follows:

(1) Every Motor Vehicle must be registered.

(2) Registration as intended in paragraph (1) includes:

a. new Motor Vehicle registration;

b. registration of change of Motor Vehicle identity and owner;

c. registration of Motor Vehicle extension; and/or

d. motorized vehicle authorization registration.

(3) Registration of Motor Vehicles as referred to in paragraph (1) aims to:

a. good administration;

b. controlling and supervising Motor Vehicles operated in Indonesia;

c. facilitate the investigation of violations and/or crimes;

d. planning, operation of Traffic and Road Transportation Management and Engineering; and

e. national development planning.

(4) Registration of Motor Vehicles is carried out by the State Police of the Republic of Indonesia through the Motor Vehicle registration management system.

(5) Data for registration and identification of Motor Vehicles is part of the Traffic and Road Transportation Information and Communication System and is used for police forensics.

(6) Further provisions regarding registration as intended in paragraph (2) shall be regulated in a regulation by the Head of the National Police of the Republic of Indonesia."

Meanwhile, specifically the ownership of BPKB, is regulated and affirmed the protection of legal certainty through Perkap No. 5/2012. For the purpose of resident about orderly administration, diction, BPKB legal protection and certainty is formulated as follows:

"Article 2 of the Resident Ranmor aims to:

a. orderly administration, in order to:

1. guarantee the validity of Ranmor and its ownership and operation

Ranmor in the context of realizing protection and legal certainty."

Apart from that, from the definition or normative definition in the registrar, it is stated that the BPKB is a means of granting legitimacy to owning a motorized vehicle. So that the protection and legal certainty of BPKB is stipulated in the current positive legal norms. The community is legally protected because of the State's recognition that the owner of the BPKB is legally valid. The legality of legal certainty is certain because it is formulated both in a Law and a Perkap. 


\subsection{Phrases Facilitate Violation and/or Crime Investigation}

Guidelines or juridical signs regarding the law of ownership of BPKP are formulated in Perkap No. 5 of 2012. In the section on Resident Ranmor objectives, the juridical formulation is as follows:

"Article 2 of the Resident Ranmor aims to:

c. facilitate the investigation of violations and/or crimes in the form of:

1. Provision of police forensic data to support the investigation of crimes related to Ranmor"

This formulation clearly states that the Resident Ranmor (BPKB) is an important means of evidence in the event of a crime or crime involving motorized vehicles. The role of police forensics is as a means of revealing crimes related to motorized vehicles, both as the object of crime (target) and predicate of crime (means or assistive devices). Thus the BPKB directly plays an important role in assisting police officers in uncovering criminal cases involving motorized vehicles.

\subsection{Phrases for Provision of Data to Support Law Enforcement against Traffic Violations}

Other juridical signs regarding the importance of BPKB ownership, can be found in the phrase Provision of Data to Support Law Enforcement against Traffic Violations. As with the flow of the enforcement process of law or law enforcement in the case of traffic violations, the strategic role of BPKB can be seen in its strength as evidence. Examination of cases in court, placing evidence as the strength of the arguments of the panel of judges in deciding criminal cases. With the rules of evidence that are VATM, Original Valid, Current and Sufficient, the BPKB plays a very important role in expressing a sense of justice in society. As the basis for the purpose of law enforcement namely upholding justice in society.

Legal protection in BPKB ownership can be classified into two things ${ }^{11}$ namely, abstract protection is basically a form of protection that can only be enjoyed or felt emotionally (psychologically), such as satisfaction. Meanwhile, concrete protection is basically a form of protection that can be enjoyed in real terms, such as gifts that are either material or non-material. Protection qualification is abstract when the BPKB owner is psychologically satisfied because of the legal certainty in implementing law enforcement in the case of BPKP guaranteed by the State. The second is concrete because the BPKB is the main evidence in terms of motor vehicle ownership.

Law enforcement against the crime of rental car embezzlement, for example, is a real case faced by the public as the legal owner of a vehicle according to the perspective of the law. As a result, law enforcement officers need to be alert in responding to criminal cases of car embezzlement so that public trust in the police institution does not decrease ${ }^{12}$. As law enforcement officers, the Police function to

\footnotetext{
${ }^{11}$ Sri Endah Wahyuningsih, "Legal Protection of Children as Victims of Crime of Decency in Current Positive Criminal Law", Journal of Legal Reform Volume III No. May 2 - August 2016, p. 173

12 Tito Dwi Anggoro, "Implementation of Enforcement Embezzlement of Rental Vehicle Crime In Polsek Banyuurip Satker Polres Purworejo", Jurnal Daulat Hukum, Volume 1, September 3 2018, p. 628
} 
enforce the law against any crime involving the BPKB, both as the object of crime and predicate of crime.

\section{Closing}

The positive law currently living in society includes the role of the State, normatively formulating that the law of ownership of proof of motor vehicle ownership (BPKB) has legal force as a means for the community to be protected and given legal certainty. So that the role of the BPKB as a valid evidence tool and its legitimacy is recognized by the State, is very strategic as a means of exposing crimes related to motorized vehicles, both as an object (target) of crime and as a predicate of crime (tool or means). BPKB's juridical ownership scheme, rooted in the Preamble of 1945 Constitution of the Republic of Indonesia up to laws and regulations such as Act No. 22 of 2009 concerning Road Traffic and Transportation as well as Regulation of the Chief of Police Number 5 of 2012 concerning Registration and Identification of Motor Vehicles. Regarding the BPKB as supporting data in the Police forensic system, the current use of technology and information in the hard BPKB format can use the latest technological advances so that fraud, embezzlement or falsification of BPKB is not easy.

\section{References}

\section{Journals}

[1] Ira Alia Maerani, Jurnal, Implementasi Ide Keseimbangan dalam Pembangunan Hukum Pidana Indonesia Berbasis Nilai-Nilai Pancasila, Jurnal Pembaharuan Hukum, Volume 2 No 2, May-August 2015

[2] Setiyanto, Gunarto, Sri Endah Wahyuningsih, Efektivitas Penerapan Sanksi Denda E-Tilang Bagi Pelanggar Lalu Lintas Berdasarkan Undang-Undang Nomor 22 Tahun 2009 Tentang Lalu Lintas Dan Angkutan Jalan (Studi Di Polres Rembang), Jurnal Hukum Khaira Ummah Vol. 12. No. 4 December 2017

[3] Sri Endah Wahyuningsih dan Rismanto, Jurnal, Kebijakan Penegakan Hukum Pidana terhadap Penanggulangan Money Laundering dalam Rangka Pembaharuan Hukum Pidana di Indonesia, Jurnal Pembaharuan Hukum, Volume 2 No 1, January-April 2015

[4] Sri Endah Wahyuningsih, Perlindungan Hukum terhadap Anak Sebagai Korban Tindak Pidana Kesusilaan Dalam Hukum Pidana Positif Saat Ini, Jurnal Pembaharuan Hukum Volume III No. 2 May - August 2016

[5] Tito Dwi Anggoro, Implementation Enforcement Embezzlement of Rental Vehicle Crime In Polsek Banyuurip Satker Polres Purworejo, Jurnal Daulat Hukum, Volume 1, 3 September 2018

\section{Book}

[1] Soerjono Soekanto and Sri Mamudji. (1985). Penelitian Hukum Normatif Suatu Tinjauan Singkat. Jakarta: Rajawali

\section{Regulations}

[1] Act No. 22 of 2009 concerning Road Traffic and Transportation 
[2] Regulation of the Head of the National Police of the Republic of Indonesia Number 5 of 2012 concerning Registration and Identification of Motor Vehicles

\section{Internet}

[1] Understanding Political Legitimacy and Power According to Experts, https://www.weschool.id/pengentuk-legitimasi-hukum-politik-dankekdaya-menurut-para-ahli/ 